Article

\title{
Suspect Outsiders or Prospective Citizens? Constructing the Immigrant/German Boundary in Germany's Integration Courses
}

\author{
Daniel Williams \\ Department of Sociology, St. Catherine University, Saint Paul, MN 55105, USA; dawilliams@stkate.edu
}

Received: 16 March 2018; Accepted: 9 April 2018; Published: 11 April 2018

\begin{abstract}
Most scholarship on integration and assimilation in Europe has examined laws, policies and quantitative data to understand the integration of immigrants. Fewer studies have looked at the meaning of integration for immigrants and host societies. This article helps to fill this gap in scholarship by examining the construction of immigrants and Germany in mandatory integration courses in contemporary Germany. Using ethnographic observations of integration courses and discourse analysis of curricular materials, I analyze these constructions using a boundary-construction approach, where both the content of what separates immigrants from host society members, and the brightness of the boundary are used as a basis for viewing immigrants as outsiders versus citizens. I use the terms suspect outsiders and prospective citizens to describe the nature of the immigrant/German boundary based on these constructions. The findings show that three themes-gender and family norms, democracy and rights, and religious freedom-form the content of the immigrant/German boundary. Within these themes, Germany's civic integration courses generally construct immigrants as prospective citizens by blurring the immigrant/German boundary. The nature of the immigrant/German boundary is crucial for both the integration of immigrants and for Germany. A bright boundary that invokes the notion of immigrants as fundamentally different places the burden of integration on them to change, while a blurred boundary potentially redefines what it means to be German.
\end{abstract}

Keywords: integration; assimilation; immigration; Germany; national identity

\section{Introduction}

In the early 2000s, Germany and other European Union countries began to introduce integration courses as part of a new emphasis on the integration of immigrants (Goodman 2014; Bertossi 2011; Joppke 2007; Council of the European Union 2004). Most European Union countries, including Germany (in 2005), France (in 2003), the United Kingdom (in 2007), The Netherlands (in 1998), Austria, Denmark, and others, introduced and currently require integration courses for most new immigrants (Joppke 2007). The goal of such courses is to aid in the integration of immigrants into the labor market, education system and everyday life by teaching them both language as well as civic and cultural information (history, politics, culture) about the host country. Successful completion of integration courses is also formally tied to residence permits, welfare benefits, work permits, entry and even family reunification (Goodman 2014), illustrating the weightiness and importance that integration has taken on as part of immigration and citizenship policies across Europe. As such, integration courses represent a continuation of the politics of membership, and have thus become a key site of boundary drawing between immigrants and Germans in contemporary Europe.

Mandatory integration courses in Germany began in 2005, as part of the 2004 Immigration Act (Zuwanderungsgesetz) (Klusmeyer and Papademetriou 2009). This law was the culmination of 
government commissions concerned with multiple immigration questions, including labor migration, the asylum process, as well as integration (Klusmeyer and Papademetriou 2009). In particular, there was a concern with high rates of unemployment of particular groups such as Turkish immigrants, as well as those groups' use of social welfare programs. Not all immigrants were or are required to take an integration course. European Union citizens are exempt based on their right to residence in any EU member country. All others seeking a residence permit, including spousal and family reunification migrants, are required to take an integration course. Integration courses are also required of anyone receiving social welfare (FOMR 2015). As a result, most integration course participants are non-European.

Germany's integration course consists of two parts: a language course of 600-900 h, followed by an 'orientation course' lasting $60 \mathrm{~h}$. This latter course-the focus of this article-usually takes place over a three- to six-week period and is centered on educating immigrants about politics, laws, history and everyday life in Germany. The integration course curriculum is standardized by the German Migration and Refugees Office, with a limited number of course books with nearly identical topics and content. All course books are divided into three units, in the following order: Politics in a Democracy; History and Responsibility; and The Individual and Society. The course concludes with a Life in Germany test that course participants take at the end of the course. This test virtually replicates the official citizenship est which migrants who wish to naturalize must take. The test consists of 33 questions drawn from a test bank of 300 questions. Those who pass the test can have their residence time for naturalization reduced by 1 year, from 8 to 7 years.

While the goal of immigrant integration through integration courses is clear, what information is deemed necessary for integration is vague. The Council of Europe's directive on integration courses simply states, 'basic knowledge of a host society's language, culture, and institutions is indispensable to integration' (Joppke 2007, p. 23). But what counts as basic knowledge? Even the modules of Politics in a Democracy, History and Responsibility, and The Individual and Society, do not reveal the knowledge used to construct Germany and deemed necessary for immigrants to know. This vagueness and ambiguity in defining integration and host-society knowledge points to the need to examine what is being taught in integration courses and how it defines the meaning of integration. As Klusmeyer and Papademetriou note, '[integration]'s meaning is subject to change and remains open to competing interpretations' (Klusmeyer and Papademetriou 2009, p. 261).

In this article, I examine integration courses in Germany as a key site for constructing both immigrant and national identities. I use a sociology of boundaries approach (Lamont and Molnár 2002) to analyze these constructions in two ways. First, I consider whether integration courses create bright or blurred boundaries (Alba 2005) between immigrants and Germans. I examine the extent to which immigrants and Germans, and their respective countries and cultures, are constructed as different and/or similar. Second, I examine the content of the boundary between immigrants and Germans that emerges in integration courses. I ask what narratives and identity categories about immigrants and Germany emerge and are salient in the integration course. I use the terms suspect outsiders and prospective citizens to capture the way that immigrants are constructed based on these two ways of analyzing the immigrant/German boundary.

My observations are based on three separate integration courses at three different sites in Germany (See Table 1). Two of the courses took place in Berlin, and one was in Frankfurt. I selected these particular courses based on prior contacts and accessibility as well as the fact that they served different groups of immigrants and were taught through different types of institutions. One Berlin-based course (herein referred to as the 'Arabic class') was offered at an Arabic community organization. All of the participants in this course were Arabic-speaking, and most were recently arrived Syrian refugees who had been in Germany for one to one and a half years. Two teachers alternated teaching the course: one was a young Polish student in her early 20s who spoke German but no Arabic; the other teacher was a Moroccan man in his 30s who had lived in Germany for a longer time and was fluent in both German and Arabic. A second class (herein referred to as the 'Turkish class') was held at a Turkish social 
services organization in Berlin, and was taught by an older German man. Despite the ethnic association of the organization, the participants in this course were of diverse national origins. The third class (the 'Frankfurt class') was held at the main Volkshochschule (continuing education school) in Frankfurt. This course was the most diverse by national origin of the three courses, with each participant coming from a different country. It was taught by a German woman in her 50s. Women and men were equally represented in all three courses. Through classroom interactions and informal conversations outside classes, I surmised that class participants often had a mix of class backgrounds and immigration statuses, with the exception of the Arabic course whose participants were all Syrian refugees.

Table 1. Description of Integration Courses Observed.

\begin{tabular}{|c|c|c|c|c|}
\hline Course & Location & Institution Type & Teacher Background & $\begin{array}{l}\text { Students' National Origin } \\
\text { and Gender }\end{array}$ \\
\hline Arabic class & Berlin & $\begin{array}{l}\text { Arab community } \\
\text { organization }\end{array}$ & $\begin{array}{c}\text { Moroccan man, mid } \\
\text { 30s; Polish woman, 20s }\end{array}$ & Syrian $(6 \mathrm{~F}, 3 \mathrm{M})$ \\
\hline Turkish class & Berlin & $\begin{array}{c}\text { Turkish social services } \\
\text { organization }\end{array}$ & German man, mid 50s & $\begin{array}{l}\text { Japanese }(1 \mathrm{~F}) \text { Turkish }(1 \mathrm{~F}, 3 \mathrm{M}) \\
\text { Lebanese }(1 \mathrm{~F}) \text { Syrian }(2 \mathrm{~F}) \\
\text { Moldovan }(2 \mathrm{~F}, 1 \mathrm{M}) \\
\text { Bulgarian }(1 \mathrm{M})\end{array}$ \\
\hline Frankfurt class & Frankfurt & $\begin{array}{l}\text { Continuing education } \\
\text { school (Volkshochschule) }\end{array}$ & $\begin{array}{l}\text { German woman, mid } \\
50 \mathrm{~s}\end{array}$ & $\begin{array}{l}\text { Peru (1F) China (1M) } \\
\text { Colombia (1F) Afghanistan } \\
\text { (1F) Iran (1F) Bangladesh (1M) } \\
\text { Pakistan (1M) South Africa } \\
\text { (1M) Hungary (1F) Bosnia } \\
\text { (1M) Poland (1M) }\end{array}$ \\
\hline
\end{tabular}

While the courses I selected were different from each other based on participants' backgrounds, institution and location in Germany, it is unclear how representative they are of integration courses generally. My findings are based on a very small sample of integration courses, largely due to the time-intensive nature of using ethnographic methods. It is difficult to know which factors, or how many, potentially influence how immigrants are constructed in integration courses. Some possibilities include course site (community organization, Volkshochschule, language school), geographic location (regionally but also urban/rural), teachers' and students' multiple identities, age, gender, and many others. The three courses I observed were different in terms of students' backgrounds, geographic location ( 2 cities), and course site (community organization versus continuing education school). While the sample size is small, the research methods were ideal for the research question, and uncommon in the study of immigrant integration.

One point of comparison that was deliberate in the selection of courses was the ethnicity/ nationality of course participants. Many studies of integration have either given no consideration to how immigrants are differentiated by social location, categories, and identities such as nation/region of origin, religion, race; or have examined immigrant integration for a specific group based on one or more categories. Informed by perspectives on intersectionality (Collins 2000) and the "situated politics of belonging" (Yuval-Davis et al. 2006), I sought to explore the comparative differences in how different groups of immigrants might be subject to different boundaries or constructions in different integration courses. While the term "immigrants" technically refers to any foreign-born person or non-citizen, immigrants in most host societies are imagined and represented in public discourse as particular groups (cf. Chavez 2013). In Germany, public discourse about immigration has focused on Muslims - the majority of whom are Turkish, Middle Eastern and Asian-or these same ethnic/national origin groups (Ewing 2008; Green 2015). In addition, comparative studies of immigrant groups in Germany have shown that Turks and Turkish-Germans are more disadvantaged than other immigrants in educational attainment as well as the labor market (Kristen and Granato 2007; Kalter 2011), and thus symbolic of the challenge of immigrant integration. For this reason, I chose integration courses held at Turkish and Arab community organizations, which serve communities 
deemed the most "Other" in public discourse. As a contrast, I chose Frankfurt as one of the most diverse cities in terms of national origin. This diversity was reflected in the backgrounds of course participants in the course I observed, who came from Asia, the Middle East, South America, Eastern Europe, and North and Sub-Saharan Africa.

The majority of the scholarship on integration has focused on either integration policy or on indicators of integration in socioeconomic, cultural and political terms, often using quantitative methods and data (e.g., Ersanilli and Koopmans 2010; Alba and Foner 2015). The strength of these studies has been their comparative approach, which has yielded important conclusions and debates about the inclusivity or restrictiveness of integration programs and requirements, including integration courses. Ersanilli and Koopmans (2010), for example, examine the influence of citizenship requirements on the socio-cultural integration of Turkish immigrants in three countries. Alba and Foner (2015) also take a mostly quantitative approach by comparing the integration of second-generation immigrants in six countries in Western Europe and North America, comparing immigrants in seven areas-economics, education, political power, residence, intermarriage, race and religion. It is from such studies that statements and measures of how 'well' immigrant groups are integrated are derived. Another strand of literature has examined integration policy, often in comparative perspective (Goodman 2010, 2014; Michalowski and Oers 2012; Joppke 2007; Jacobs and Rea 2007). Much of this literature attempts to develop typologies and indexes for integration across European states, as well as to argue in favor of, or against, the convergence of integration policy and programs among countries. Some of this work has also taken a critical approach, questioning whether integration policies and programs in fact lead to the desired outcome of integrating immigrants (Goodman 2010; Goodman and Wright 2015). Other critical work has examined the use of integration programs as a tool of racial and ethnic projects (Fitzgerald et al. 2017) or as a tool of immigration control (Goodman 2011). These various approaches to studying integration have been illuminating in bringing a comparative perspective on policies as well as outcomes across groups, but in general have remained focused on integration policy, and/or quantitative measures of integration.

By definition, integration involves questions of national identity-what the nation is defined as and how it is imagined (Anderson 1991). The scholarship on nations, nationhood and national identity is, therefore, important to understanding the immigrant/German boundary. As this literature shows, nations have historically used various criteria and categories as a basis for their self-definition, from civic principles to group memberships based on ethnicity, language, religion, race and others (Brubaker 1992; Hobsbawm 1990; Anderson 1991; Joppke 1998; Beaman 2015; Simonsen 2016; Fitzgerald et al. 2017). Such constructions shape self-understandings and senses of belonging for both citizens and non-citizens, and inform policies and practices of membership and inclusion (Brubaker 1992, 2013; Bail 2008; Triandafyllidou 1998; Chávez et al. 2012; Onasch 2017). For example, Brubaker (1992) seminal comparison of France and Germany showed how differences in national self-understandings (civic/territorial versus ethnic) led to liberal or restrictive access to citizenship. Similarly, Favell $(2001,2003)$ compared philosophies of integration in Britain, France and the US, and their impact on policies as well. Other scholarship has shown that integration and citizenship may be more or less 'ethnicized,' based on political parties' differing definitions of who belongs to the nation (Joppke 2006). Importantly, these definitions and constructions of national identity simultaneously construct non-members and 'others' defined as excluded or outsiders (Simonsen 2016; Triandafyllidou 1998). At the same time, the specific narratives or identities used in the constructing of nations has varied and is contested. This means that while host societies have always been concerned with immigrant integration or assimilation, those concerns are framed in various terms and categories, and with particular stories or tropes about specific groups who fall into those categories (Bail 2008; Helbling 2014; Ewing 2008; Allievi 2005). Zolberg and Woon's (1999) article title-_Why Islam is like Spanish' - captures this fundamental way in which different categories, such as religion or language, may do the same kind of boundary work. While Spanish, a language, may be deemed a threat to national identity in the USA, Islam, a religion, may be seen as a threat to national identities in Europe. 
Like the scholarship on integration, the scholarship on nations, nationalism, and national identity has been largely at the macro-level. However, nations and immigrants are also constructed and imagined at the micro-level, through interactional processes, often in local contexts. While large-scale data comparing statistics on unemployment and education or citizenship policies are more often used to analyze boundaries between immigrants and citizens, such approaches cannot account for interactional or local contexts, and risk overgeneralizing national models (see cf. Simonsen 2016). Integration courses represent such contexts.

Integration courses are in fact, by definition, sites for the making of national identities, as they have the specific goal of teaching about the nation and host society. Scholars such as Eugen Weber have shown that education has been a key tool in the making of national identities. As Soysal and Schissler note: '[h]istorically, subjects were transformed into citizens through the teaching of history, geography, and the language of the nation' (Soysal and Schissler 2005). Integration courses and their curricula represent a 'codified and legitimized version of what is worth knowing and what is right and wrong because they speak with the institutional authority of their principal user: the educational system, that is, to some degree at least, the state' (Kotowski 2013, p. 301).

Previous scholarship has defined integration and citizenship almost entirely through the numbers of barriers to nationality acquisition or requirements for residence and naturalization (cf. Howard 2009; Goodman 2010; Fitzgerald et al. 2017). Yet, a key aspect of belonging and becoming a member of a society is based on the permeability of the boundary, which in turn depends on constructed understandings of immigrants, host societies and the meaning of membership. As the comparative study of citizenship and national identity has shown, how national identity is understood is critical for both whether immigrants choose to become full members through naturalization, and what that membership means (Chávez et al. 2012; Brubaker 1992; Williams 2013). It is therefore critical to examine the meanings of immigrants and host nations.

To examine these constructions, I use a sociology of boundaries approach (Lamont and Molnár 2002; Zolberg and Woon 1999; Alba 2005; Korteweg and Triadafilopoulous 2013; Onasch 2017; Wimmer 2008). Zolberg and Woon (1999) have most clearly developed the boundary construction approach to the study of immigration. Specifically, they introduced the concepts of boundary 'crossing', 'blurring' and 'shifting.' According to their formulation, incorporation and inclusion are part of a negotiated, dialectical process of boundary drawing between hosts/Germans and immigrants. Boundary crossing occurs when individuals 'change themselves by acquiring attributes of the host society'; boundary shifting occurs when 'the line differentiating members from non-members is relocated'; finally, boundary blurring is characterized by the 'tolerance of multiple memberships and an overlapping of collective identities hitherto thought to be separate and mutually exclusive' (9). Alba (2005) further expanded on this language by introducing the distinction between 'bright' boundaries-or those where 'individuals know at all times which side of the boundary they are on'-versus 'blurred' ones, which 'allow for ambiguous locations with respect to the boundary' (22). Using race, religion, citizenship and language, he compares the second generation in France, Germany and the US. Based on these categories, he shows that the two European societies create a brighter boundary between immigrants and Germans than does the US (39).

I combine the sociology of boundaries' methodology with ethnography and discourse analysis (Tonkiss 2012) as specific methods of data collection to analyze the immigrant/German boundary. Critical discourse analysis focuses on the way that ideologies are reproduced through language and texts,' as well as the way that language is crucial to the reproduction, legitimation and exercise of power (Tonkiss 2012, p. 408). Language is about both categories or what is said, and reflects statements which can reproduce or, alternatively, challenge existing power relations. Within the study of immigration, a few studies have examined integration using ethnographic or discourse analytic approaches. Two important contributions are Korteweg and Triadafilopoulous (2013) and Onasch (2017), both of which analyze the meanings of immigration and integration using discourse analysis or ethnographic methods. Korteweg and Triadafilopoulous (2013) examine the way that 
parliamentary debates about integration in the Netherlands construct immigrants. They find that parliamentary debates centered on Muslim women, rather than all immigrants, as the intended targets of integration programs. In addition to showing the importance of representations and stereotypes in the discourse on integration, their analysis illustrates that integration programs imagine immigrants as particular kinds of people (cf. Hacking 1986), which in turn inform policymaking and programs. Similarly, Onasch (2017) work on boundary drawing in the French integration program illustrates the ways immigrants are represented and treated in integration courses, and finds that essentialized stereotypes of religion, culture and race, emerge through interactions between students, course instructors and other personnel involved in integration programs.

Germany's Migration and Refugees Office has a standardized curriculum with specific course books with nearly identical content. However, it is the realization of that content through examples, illustrations and elaborations chosen by teachers, as well as the interactions between students and teachers about some topics and not others, that construct the boundary between immigrants and Germans/Germany, and constitute immigrants as suspect outsiders or prospective citizens. It is through this process that meanings of 'immigrants,' 'Germans' and 'Germany,' are made. The curriculum and the interactions that arise in its context are deeply interwoven and, therefore, I analyze both the text of the curriculum and the spontaneous interactions and conversations between teachers and students and among students. Examples, illustrations and elaborations on course material can have very different meanings about immigrants and Germans/Germany. For example, in teaching the principle of 'freedom of religion,' a teacher could ask a participant, 'Can you force others to wear the hijab?' Such a question constructs religious freedom as freedom from a Muslim practice and symbol of Islam, with the accompanying narrative of Muslims as religious zealots who try to convert others to Islam. Such an example brightens the boundary between immigrants and Germans/Germany and views immigrants as suspect outsiders. Other interactions may blur the boundary of Germans and immigrants by emphasizing the citizen-ness of immigrants. For example, teachers' elaborations may include an emphasis on the rights of immigrants to practice religion or other cultural practices, which suggest their ability to belong in Germany without discarding their identities.

Examples such as those above construct not only the boundary separating immigrants and Germans, but also the boundary between Germany and immigrants' countries of origin. In integration courses, the host society may be idealized and presented as superior to immigrants' countries of origin. I therefore took note of when Germany and Germans were idealized compared to immigrants and their countries of origin. I interpret those instances when Germany was idealized as cases of bright boundary drawing. Using the same approach, I also paid attention to the critiques of Germany offered in the curriculum, classroom and in interactions. I analyzed these examples as well as others where Germany was seen as 'no better' as instances of boundary blurring, since in doing so immigrants were constructed as equals who did not necessarily need to change or assimilate to become integrated, and were therefore prospective citizens.

Because these elaborations are spontaneous, interactive, and take place in real time, ethnographic methods are ideal for analyzing the immigrant/German boundary. For each course, I observed roughly half of the 60 total hours of each integration course. Following Emerson et al. (2011), I closely observed and took field notes in a small notebook on classroom and course site settings, course participants' backgrounds, and interactions within the classroom as well as outside it, and before, during and after class. I also took notes of interactions I had with students and teachers during and outside of class. I specifically listened for instances where teachers' examples, illustrations, and elaborations that were occasions for boundary drawing between immigrants and Germans. I later reviewed these notes for themes where immigrants could be constructed as suspect outsiders or prospective citizens, and then coded them using the themes I examined. 


\section{Results}

\subsection{Constructing Immigrants and Germany in Real Time: Teachers and Elaborating Examples}

In the integration courses I observed, three themes emerged as important for constructing the immigrant/German boundary: (1) gender relations and gender equality; (2) democracy and rights; and (3) religious and expressive freedom. These were the themes that elicited the most interactions, elaborations and conversations among teachers and students in the courses I observed. They are also themes that are central to both policy and public discourse about immigrant integration in Europe (Goodman 2014; Green 2015; Ewing 2008). Below, I examine 11 instances where the boundary between immigrants and Germans was elaborated through interactions and examples between teachers and students (See Table 2). These 11 occasions represent all of the instances I observed where the immigrant/German boundary was constructed through the three themes I examine. Of these 11 instances, two (2) were ones in which the immigrant/German boundary was brightened. The remaining nine (9) cases were all examples of blurring the immigrant/German boundary. Three of the 11 instances were under the theme of "Freedom of Religion and Expression"; Five were about "Gender and Family Norms"; and four were about "Democracy and Rights." These results show that immigrants in integration courses are more often viewed as prospective citizens than as suspect outsiders.

Table 2. Immigrant/German boundary drawing in integration courses.

\begin{tabular}{cccc}
\hline Thematic Area & Specific Topic & Boundary Type & Course \\
\hline \multirow{4}{*}{ Gender and Family } & Gender inequality & Blurred & Frankfurt class \\
Norms & Child/forced marriage & Blurred & Turkish class \\
& Polygamy & Blurred & Turkish class \\
& Forced marriage & Blurred & Arabic class \\
& Child abuse & Bright & Arabic class (students) \\
\hline \multirow{2}{*}{ Democracy and Human } & Torture/human rights & Bright & Frankfurt class \\
Rights & Voting rights & Blurred & Turkish class \\
& Discrimination & Blurred & Turkish class \\
& Islamophobia & Blurred & Turkish class \\
\hline Freedom of Religion and & Freedom of religious affiliation & Blurred & Frankfurt class \\
Expression & Criticism of German gov't. & Blurred & Frankfurt class \\
\hline
\end{tabular}

In terms of course materials, instructors alternated between the course book, their own handouts and practice questions that may appear on the Life in Germany test. Teachers seldom followed course books exactly or thoroughly. The majority of interactions between teachers and students were not occasions for constructing the immigrant/German boundary. Rather, most of the class time in integration courses was spent communicating and clarifying factual information, explaining German words, and practicing sets of questions found on the "Life in Germany" test without further elaboration. What was common across courses was teachers' tendency to use examples and elaborations to make otherwise abstract concepts, laws and principles relevant and understandable to course participants. It is most often through this process that the immigrant/German boundary was constructed. Observing integration classes was, therefore, all the more critical for understanding whether integration courses brighten or blur the immigrant/German boundary.

\subsubsection{Gender and Family Norms}

Gender appears mainly in the Politics in a Democracy and The Individual and Society units of the course. As a key part of Article 3, 'Equality before the law,' the anti-discrimination clause, which states that all persons are equal before the law regardless of gender, sex, parentage, race, language, national origin, faith, religious or political opinions or disability, section (2) reads, 'Men and women shall have equal rights. The state shall promote the actual implementation of equal rights for women and men and take steps to eliminate disadvantages that now exist.' In The Frankfurt class, the teacher followed 
reading this article with a question to the class, 'How is it in reality? Are men and women equal? In terms of the wage gap, for instance?' Various students in the class replied 'No'. While this exchange between teacher and students was brief, it reflected a critique of Germany as a society without gender equality. Notably, the teacher made no comparison to gender equality in students' countries of origin, nor asked them whether they agreed with the equality principle.

In another class, gender and family norms were also elaborated on by teachers. In a practicing questions session in the Turkish class, the teacher prefaced a question by saying, 'this question always shows up on the test: "Who of the following is not allowed to live together as a couple?"' The correct answer is 'Anne (13 years old) and Tim (25 years old).' All of this was said in a dismissive tone, suggesting either the teacher's mocking attitude towards a question aimed at Muslim immigrants as practicing 'forced marriage,' (Ewing 2008), or that the question was unimportant or not worth emphasizing. The teacher followed this example with another question on marriage: 'Which lifestyle is not allowed in Germany?' to which the answer was one man is married to two women.' He then asked, 'Why do they ask this question? Maybe because they assume that all immigrants have 10 wives!' To this, a Syrian woman responded, 'Where we're from, maybe two. But it's expensive!' Here, the teacher critiqued a dominant narrative in immigrant integration debates-the Muslim polygamist (Ewing 2008). One of the alternative answers to the same question of 'lifestyles' was 'two men,' illustrating the acceptability of same sex partnerships and homosexuality. As other studies have shown, acceptance of homosexuality has been emphasized in the integration programs of many European countries. Thus, the teacher's avoidance of this common 'baiting' topic is notable. In both of the above examples, the teacher could have illustrated these practice questions with examples that would have implied Muslims as suspect outsiders, but instead mocked the questions' presumptions of immigrants as polygamous and backward in their marriage practices.

These suspicions of immigrants as polygamous emerged in the Arabic class as well. On the second day of class, the teacher passed out a two-page handout entitled The Individual and Society, the same title as the third module of all integration courses. On the handout, several terms appear in bold (roughly 80, or about one every sentence). Many sentences are followed by the question number on the Life in Germany test, making the document a learning tool for the "Life in Germany" test.

The section on the handout on marriage and the family begins as follows:

Both the man and the woman must apply for marriage at the registration office. Only one man and one woman may be married. Belonging to a different religion does not matter. Both must be majority age (18), or in exceptional cases (16). The parents of the couple must accept their decision, even when they do not like it.

In this excerpt, there are several clear emphases: both genders must apply for marriage license-in other words, men may not marry women without women's consent; one can only be married to one other person; and parents have no power or authority in a child's partner choice. Each of these emphases reinforces dominant narratives about immigrants—specifically Muslims—about polygamy as well as arranged/forced marriage. Such representations are consequential, having been used in actual immigration policies such as the 2007 amendment to the minimum age of spousal migrants (Ewing 2008, p. 164).

In the same class, another passage from the same handout provoked interest and a spontaneous discussion from the participants:

\section{A child who is beaten or hungry can be taken away from the family and placed in a shelter or} foster care.

Here, the idea that immigrants beat their children is implied. The teacher on this day, a young Polish woman, elaborated on this point, saying 'The Child Welfare Office can come and take your child away!' in an alerting, but not especially disciplinary tone. To this, one of the participants replied, 'A child without parents?' Another class participant then began to tell a story, in German, of her 
neighbor whose son went to kindergarten with bruises on his arms. 'The teacher saw these bruises and called the child welfare office,' she explained, 'but the child had just fallen down.' This anecdote was followed by exasperated reactions from other class participants. This exchange in which multiple students were engaged and clearly interested, illustrated two views immigrants may have about Germany: the German state can and will in some cases take your children away; and it may do so for the wrong reason. Through this example and interaction, participants clearly sensed themselves as suspect outsiders based on who the state mistakenly thought they were. But they also saw themselves as powerless and potentially victimized by the state and, moreover, powerless to hold their family together. In this example, the boundary between immigrants and Germany was brightened by both the mistaken belief about immigrant non-conformity to German family norms, and that the German state's power over immigrants was absolute. The resonance of this story told by an immigrant in class was a unique and rare occasion in the integration courses I observed, where immigrants articulated their perceptions of the German state.

\subsubsection{Democracy and Human Rights}

The importance of democracy in the German integration course is underscored as one of the three main units in the integration course curriculum. But how might a system of government become the basis for drawing the immigrant/German boundary? Democracy is increasingly an espoused value of nation-states, especially in Western Europe, and Germany in particular given the Nazi past. Similarly, 'rights' and 'human rights' have been principles through which nation-states, including Germany, define themselves. Because nation-states use democracy and rights in defining their national identity, these can become a basis for drawing a boundary between immigrants and the host society. From a boundary construction perspective, it is not the fact or existence of democracy as a form of government in Germany per se, but the foregrounding and highlighting of these as qualities that define Germany that makes them an occasion for boundary construction. Scholarship has also shown that "democracy" and "rights" as values can become a proxy for religious and national categories ('Muslim', 'non-European') (Ewing 2008). Democracy and rights were important topics in integration course instruction and interactions.

The Frankfurt class, held at the continuing education school, began with 'Politics in a Democracy,' the first unit in Politics, History, and Society in Germany (Schotte 2011) and of all course books. The text begins with a section titled 'Human Dignity,' followed by, 'Democracy is only possible when human beings have basic rights' (Schotte 2011, p. 10). Following the text, the teacher proceeded to go through Articles 1 through 6, and 11 and 16 of the German Basic Law (or Constitution), which include the basic rights. The teacher asks course participants what the term 'human dignity' means, an abstract question which no one volunteered to answer. The teacher then proceeded to explain the term by using 'torture' as an example of the violation of human dignity. She asked students, 'in the countries where you come from, is there torture? From what we hear in the media ... ' She went on to discuss several examples from various countries around the world, including the specific example of Peru. This question and discussion yielded no responses or discussion from course participants, despite the fact that some of the students were likely to be asylum seekers and, in fact, one was Peruvian. Like in all of the classes I observed, the teacher must continually make efforts to keep students engaged. In this instance, in maintaining the 'engagement' of students by implying the relevance of topics to them, the teacher otherized students by suggesting they might be from places where torture is practiced, while contrasting those countries with Germany where 'human dignity' is a basic right in the Constitution. This instance highlighted, rather than blurred, the difference between Germany and immigrants' countries of origin.

The Turkish class, taught by an older, experienced German man, began with a focus on democracy and rights. On the second day of class, the instructor passed out a handout of Life in Germany test questions on 'Rights and Duties.' Clarifying the right to vote, the teacher said to students, 'you are not required to vote!' He followed this with a question to course participants: 'How many people 
vote in Germany?' After a long pause he answered, 'very few . . 60 percent.' 'Always less!' 'Not good.' This brief elaboration does important boundary work. The teacher illustrated the meaning of a right, while reminding students of the fact that they are not required to participate in a fundamental practice of democracy. In the contemporary context, immigrants are suspected of being anti-democratic, either by choice or as a result of their 'culture' or religion. In this instance, the teacher does not treat immigrant students as if they must learn and participate in democracy in order to belong or be included. Furthermore, by citing the low levels of voter turnout in Germany, he de-idealizes Germany as a model of democracy.

The Class 2 instructor later raised another example about rights. Using a self-generated handout with practice test questions, he read question 262: 'What is the meaning of the Equal Protection Law in Germany?' The correct answer is, 'No one may be disadvantaged based on being disabled, for example.' The teacher then wrote the word 'disabled' on the board, and asked the class 'why is this so important?' Before anyone answered, he wrote the words 'Hitler', 'black', 'Jewish', 'sick' on the board, followed by the word pairs 'man/woman', 'black/white', 'young/old', 'sick/healthy'. He then wrote under these terms in bold letters, the word 'discrimination'. Importantly, the term 'discrimination' did not appear in the question or the answer. By using the term, the teacher in fact acknowledged a practice and experience that immigrants could face. The teacher also rendered the law relevant to immigrants. While the test question's answer drew on the category of bodily ability, the instructor's elaboration linked this to other statuses and categories such as race, gender and religion, which often serve as a basis for arguing immigrants' difference. He also tied the equal protection principle to the racist Nazi past. Through these elaborations and explanations, the instructor treated course participants as prospective citizens, by specifying a right they are entitled to and which may be important-and also by noting that discrimination is part of Germany's past and present. In another interaction, during a coffee break for Class 2, a male participant from Bulgaria asked the instructor, 'why is this information about politics and history so important?' This was an opportune moment to hear how teachers, as representatives of the state, frame democracy in relation to national identity. In this case, the teacher replied in a passionate voice, 'For the last 50 years all we've had is war ... The people are simply too dumb ... I don't trust the people. For example, Switzerland has direct democracy; no minarets can be built there anymore.' Here, the teacher did more than offer his personal opinion about democracy. He used anti-Muslim policies as a negative consequence of 'too much' democracy, suggesting that democracy is imperfect and even dangerous. His example also acknowledged the undesirable existence of the Islamophobia in Europe.

\subsubsection{Freedom of Religion and Expression}

Freedom of religion and expression have been dominant themes in European and German discourses on immigrant integration and national identity since formal integration policies began. In addition, one of the most powerful categories through which immigrants' assimilability in Germany and Europe has been discussed is that of 'Muslim' (Allievi 2005; Schiffauer 2006). The teacher in the Frankfurt class, which began with the basic rights in the Constitution, addressed this topic through a discussion of Article 4 of the German Basic Law, 'Freedom of faith and conscience,' which states: '(1) Freedom of faith and of conscience, and freedom to profess a religious or philosophical creed, shall be inviolable; (2) The undisturbed practice of religion shall be guaranteed.' After reading this article slowly and clearly, the teacher asked the class, 'Do you have to be Christian (to live in Germany)?' Several students answered 'No.' Most narratives about religion and immigration pose Islam as an aggressive religion, and Muslims as proselytizing religious zealots or violent extremists (Green 2015). The teacher countered this discourse by centering Christianity, rather than Islam, and by asking a question which reaffirmed immigrants' freedom from Christianity. The teacher took the abstract category of 'religion' and the principle of 'religious freedom' and used Christianity as a negative example. In doing so, she blurred the difference between immigrants and Germany by suggesting that one can belong in Germany without being Christian. 
The same teacher followed this discussion with Article 5, 'Freedom of expression,' which states, '(1) Every person shall have the right freely to express and disseminate his opinions in speech, writing and pictures, and to inform himself without hindrance from generally accessible sources.' To illustrate this principle, she stated: "'Chancellor Angela Merkel is a stupid cow!" Can I say that?' to which a student replied 'Yes!' By affirming the acceptability of criticizing the current government, the instructor illustrates immigrants' right to use freedom of speech to disagree with the German state and its representatives. The example further counters a hegemonic meaning of 'freedom of speech,' used by conservative parties in Germany, France and elsewhere, which became a rallying cry of the West in the wake of the Charlie Hebdo attacks carried out in France. This attack symbolically reinforced and aligned 'freedom of speech' with France/the West, while distancing Islam from the same value (Green 2015). In contrast, the teacher's example relocates 'Freedom of speech' from speech about Muslims to speech about Germany, Germans and non-Muslims.

\section{2. 'Please Don't Be Late!' Frontline Workers and Disciplining Immigrants}

While teachers were indeed the most important personnel and staff in teaching the integration course curriculum, the 'program coordinators' at the sites offering the courses also played a role in constructing the immigrant/German boundary, albeit a minor one. It was only at the Berlin courses, both of which were held at ethnic community organizations, where these coordinators made appearances or were visible to course participants. In each case, the coordinator shared the cultural identity the organization represented. The coordinator of the Arabic community center was a woman of Palestinian and German background who was a German citizen and spoke both Arabic and German. The coordinator of the Turkish social service organization was a Turkish man with German citizenship who spoke German as well as Turkish. The Frankfurt course, which was held at the continuing education school, also had a coordinator, who was of Turkish background but who never checked in on classes nor was known to students.

Both program coordinators at the community organizations offering courses in Berlin would stop by or open the door to the classroom at random times. They both scolded students for not being on time or showing up often. In the Arabic class, after noticing several people coming late to class, the coordinator opened the door and simply stared disapprovingly at the class and then said sternly, 'Please don't be late!' A couple of days later, there was only one student and myself waiting who were on time. She came to check and, clearly frustrated, remarked: 'I'm looking forward to the day they have to get a job. Germany is too generous. One day when the tap is turned off, they'll come crying.'

In the Turkish class, on the second day of the class, the program coordinator unexpectedly opened the class door and started shouting at the entire class in Turkish. This was despite the fact that only 2 to 3 of the 10 participants were Turkish. He threw in a few German words-'stomach ache,' 'problems' - that quickly made it clear that he was angry about the excuses people gave for not coming to class. A few more Turkish words were then followed by 'We pay 160 euros!', and finally, 'Foreigners Office, no residence permit!' In addition to chastising the students for their excuses, he also reminded them that the organization is paying for each student's participation, and that if they don't pass the test, they will not get residence in Germany.

Overall, these brief moments showed program coordinators taking a disciplinary attitude towards immigrants. Their statements and admonitions clearly constructed immigrants as outsiders, who were not doing what is needed to integrate. It is also noteworthy that some of the specific complaints reproduce and repeat the discourse of the integration course and policy-the importance of being on time, making appointments, the immigrant as welfare dependent, and the official policy of integration course completion being tied to residence permits.

\section{Discussion}

In this article, I have examined the ways in which the immigrant/German boundary is drawn in Germany's mandatory integration courses. Based on my observations, three dominant themes emerged 
as important for viewing immigrants as either suspect outsiders or prospective citizens: (1) gender relations and gender equality; (2) democracy and rights; and (3) religious and expressive freedom. These were the themes that elicited the most interactions, elaborations and conversations among teachers and students in the courses I observed. My analysis of course content and interactions between teachers and students on topics related to these themes shows that immigrants were more often constructed as prospective citizens than suspect outsiders. This was shown through multiple spontaneous instances where teachers, elaborating on curricular material, tended to play down dominant stereotypes, themes and narratives about immigrants as patriarchal, religious zealots, and as ignorant or infantile in their knowledge about democracy and rights. In contrast, teachers' examples and use of texts emphasized the rights and potential inclusion of immigrants, as well as critiquing Germany's own adherence to the same values and themes through which immigrants are assessed.

On the one hand, these results are surprising. The current debate about immigrants and recent refugees in Germany has led to the rise of a far-right party (Alternative for Germany) within the mainstream, as well as a visible far-right movement (PEGIDA), both within the last five years. In addition, a few high-profile incidents involving migrants or those believed to be migrants, such as the sexual assaults in Cologne on New Year's Eve in 2015, were interpreted and framed by mainstream media and many Germans as confirming beliefs about immigrants as suspect outsiders (The New York Times 2016). These events and their framing in the media echo others of the past decade, such as honor killings and forced marriages (Ewing 2008). Notably, these narratives were implicit or explicit in the integration course curriculum and test questions. However, they were subverted by teachers' examples and elaborations, which ranged from mocking questions directed at Muslims to critiquing Germany's own adherence to the values that immigrants are expected to learn in order to integrate. This leads to the question of teachers as the frontline workers of integration courses and integration. In the courses I observed, teachers were clearly critical of right-wing and conservative positions on immigrant integration. Whether this is common among German teachers is uncertain, and it should be noted that teachers may not be reflective of the general population, so that how immigrants will be viewed in everyday life in Germany may be different than how teachers view and construct them.

As my analysis and findings show, ethnographic methods are especially illuminating of the boundary-construction process. Nations and immigrants are not only imagined at the macro-level or through state policies, but are equally constructed at the micro-level and in interactional contexts. Examining these micro-level sites of boundary construction may reveal a more nuanced image of nations as having 'bright' or 'blurred' boundaries of belonging. Micro-level and ethnographic studies may reveal a blurred boundary in a 'bright boundary' nation-state; or it may illustrate other important aspects of boundary construction that are otherwise missed by only analyzing statistics and state policies. Historically, Germany has been characterized by 'bright' boundaries (Alba 2005), yet in the particular cases examined here, the boundaries between Germany/German and immigrants were more often blurred than bright. At the same time, because the data and findings are based on a very small number of specific cases, it is difficult to know how representative they are of integration courses generally.

Importantly, boundaries of outsiderhood or belonging can be constituted as much by adherence to values such as religious freedom and gender equality, as by categories of difference such as national origin, religion and ethnicity/race. In the explicit discourse of the German integration course, the basis for boundaries was almost entirely through adherence to values. On the one hand, this could signal a potential re-defining of belonging and even Germanness-against the historical basis of descent or 'ethnicity' (Williams 2013; Howard 2012; Miller-Idriss 2006). On the other hand, 'values' can become a proxy for group membership, particularly in a global context in which ascribed statuses such as race, religion and others are illegitimate criteria for exclusion (Fitzgerald et al. 2017). Because values may in fact do the work that categories once did, and many of these categories in fact overlap, I have used the terms suspect outsiders and prospective citizens in place of specific categories of difference. Just as importantly, these values are as universal as they are particular to Germany. 'Human rights,' 
'democracy' and 'gender equality' all belong to a larger global, universalist discourse to which many nation-states subscribe. In this way, Germany, and Germanness have themselves been defined in universalist terms, fusing national identity with global, universalist principles. But again, this does not mean that immigrants cannot be excluded or seen as outsiders.

I approached the selection of courses through a comparative and intersectional perspective with an interest in how courses serving different groups of immigrants might differ in drawing the immigrant/German boundary. Based on my observations, there was little difference between the Turkish, Arabic and Frankfurt classes, or teachers' interactions with students of different national origins or religions. Although initially I conducted focus groups with students at the beginning of my research to know whether participants felt more like citizens or outsiders, these proved difficult due to language and other barriers.

Integration courses are one site of many where immigrants learn what they must know and do in order to potentially belong. Based on the observations here, Germany's integration courses may contribute to immigrants' sense that crossing the boundary of Germanness or citizenship is possible. However, boundaries between immigrants and host societies and their members are made at multiple sites and through an ongoing process of negotiation (Zolberg and Woon 1999). Integration courses are only one site where this boundary is made, but which is also the main way that the state creates citizens out of immigrants.

Acknowledgments: This work was supported by a 2015 Research Grant from the German Academic Exchange Service (DAAD) under (Grant 57130097).

Conflicts of Interest: The author declares no conflict of interest.

\section{References}

Alba, Richard. 2005. Bright versus Blurred Boundaries: Second Generation Assimilation and Exclusion in France, Germany, and the United States. Ethnic and Racial Studies 28: 20-49. [CrossRef]

Alba, Richard, and Nancy Foner. 2015. Strangers No More: Immigration and the Challenges of Integration in North America and Western Europe. Princeton: Princeton University Press.

Allievi, Stefan. 2005. How the Immigrant has become Muslim. Revue Européene Migration Internationales 21: 135-63. [CrossRef]

Anderson, Benedict. 1991. Imagined Communities: Reflections on the Origin and Spread of Nationalism, 2nd ed. London: Verso.

Bail, Christopher A. 2008. The Configuration of Symbolic Boundaries against Immigrants in Europe. American Sociological Review 73: 37-59. [CrossRef]

Beaman, Jean. 2015. Boundaries of Frenchness: Cultural Citizenship and France's Middle Class North African Second-Generation. Identities: Global Studies in Culture and Power 22: 36-52. [CrossRef]

Bertossi, Christophe. 2011. National Models of Integration in Europe: A Comparative and Critical Analysis. American Behavioral Scientist 55: 1561-80. [CrossRef]

Brubaker, Rogers. 1992. Citizenship and Nationhood in France and Germany. Cambridge: Harvard University Press.

Brubaker, Rogers. 2013. Categories of Analysis and Categories of Practice: A Note on the Study of Muslims in European Countries of Immigration. Ethnic and Racial Studies 36: 1-8. [CrossRef]

Chavez, Leo. 2013. The Latino Threat: Constructing Immigrants, Citizens, and the Nation, 2nd ed. Stanford: Stanford University Press.

Chávez, Leo, Louis DeSipio, Jens Schneider, and Mary Waters. 2012. Belonging. In The Changing Face of World Cities. Edited by Maurice Crul and John Mollenkopf. New York: Russell Sage Foundation, pp. 206-32.

Collins, Patricia Hill. 2000. Black Feminist Thought, 2nd ed. New York: Routledge.

Council of the European Union. 2004. Common Basic Principles for Immigrant Integration Policy in the EU. Available online: http:/ / www.eesc.europa.eu/resources/docs/common-basic-principles_en.pdf (accessed on 10 January 2017).

Emerson, Robert M., Rachel I. Fretz, and Linda L. Shaw. 2011. Writing Ethnographic Fieldnotes, 2nd ed. Chicago: University of Chicago Press. 
Ersanilli, Evelyn, and Ruud Koopmans. 2010. Rewarding Integration? Citizenship regulations and the socio-cultural integration of immigrants in the Netherlands, France, and Germany. Journal of Ethnic and Migration Studies 36: 773-91. [CrossRef]

Ewing, Katherine. 2008. Stolen Honor: Stigmatizing Muslim Men in Berlin. Stanford: Stanford UP.

Favell, Adrian. 2001. Philosophies of Integration: Immigration and the Idea of Citizenship in France and Britain, 2nd ed. New York: Palgrave.

Favell, Adrian. 2003. Integration nations: The nation state and research on immigrants in Western Europe. Comparative Social Research 22: 13-42.

Fitzgerald, David, David Cook-Martín, Angela S. García, and Rawan Arar. 2017. Can you become one of us? A historical comparison of legal selection of 'assimilable' immigrants in Europe and the Americas. Journal of Ethnic and Migration Studies. [CrossRef]

Goodman, Sara Wallace. 2010. Integration Requirements for Integration's Sake? Identifying, Categorising and Comparing Civic Integration Policies. Journal of Ethnic and Migration Studies 36: 753-72. [CrossRef]

Goodman, Sara Wallace. 2011. Controlling Immigration through Language and Country-Knowledge Requirements. West European Politics 34: 235-55. [CrossRef]

Goodman, Sara Wallace. 2014. Immigration and Membership Politics in Western Europe. Cambridge: Cambridge University Press.

Goodman, Sara Wallace, and Matthew Wright. 2015. Does Mandatory Integration Matter? Effects of Civic Requirements on Immigrant Socio-economic and Political Outcomes. Journal of Ethnic and Migration Studies 41: 1885-908. [CrossRef]

Green, Todd. 2015. The Fear of Islam: an Introduction to Islamophobia in the West. Minneapolis: Fortress Press.

Hacking, Ian. 1986. Making up People. In Reconstructing Individualism. Edited by Thomas C. Heller, Morton Sosna and David E. Wellbery. Stanford: Stanford University Press, pp. 161-71.

Helbling, Marc. 2014. Framing Immigration in Western Europe. Journal of Ethnic and Migration Studies 40: $21-41$. [CrossRef]

Hobsbawm, Eric. 1990. Nations and Nationalism since 1780. Cambridge: Cambridge University Press.

Howard, Marc. 2009. The Politics of Citizenship in Europe. Cambridge: Cambridge University Press.

Howard, Marc. 2012. Germany's Citizenship Policy in Comparative Perspective. German Politics and Society 30: 40-51. [CrossRef]

Jacobs, Dirk, and Andrea Rea. 2007. The End of National Models? Integration Courses and Citizenship Trajectories in Europe. International Journal on Multicultural Societies 9: 264-83.

Joppke, Christian. 1998. Immigration and the Nation-State: The United States, Germany, and Great Britain. New York: Oxford University Press.

Joppke, Christian. 2006. Citizenship between De-ethnicization and Re-ethnicization. In Migration, Citizenship, Ethnos. Edited by Goekce Yurdakul and Michal Bodemann. New York: Palgrave Macmillan, pp. 63-91.

Joppke, Christian. 2007. Beyond National Models: Civic Integration Policies for Immigrants in Western Europe. West European Politics 30: 1-22. [CrossRef]

Kalter, Frank. 2011. The Second Generation in the German Labor Market: Explaining the Turkish Exception. In The Next Generation: Immigrant Youth in a Comparative Perspective. Edited by Richard Alba and Mary C. Waters. New York and London: New York University Press, pp. 166-84.

Klusmeyer, Douglas, and Demetrious Papademetriou. 2009. Immigration Policy in the Federal Republic of Germany. New York: Berghahn Books.

Korteweg, Anna, and Triadafilos Triadafilopoulous. 2013. Gender, Religion, and Ethnicity: Intersections and Boundaries in Immigrant Integration Policy Making. Social Politics 20: 109-36. [CrossRef]

Kotowski, Jan. 2013. Narratives of Immigration and National Identity: Findings from a Discourse Analysis of German and U.S. Social Studies Textbooks. Studies in Ethnicity and Nationalism 13: 295-318. [CrossRef]

Kristen, Cornelia, and Nadia Granato. 2007. The educational attainment of the second generation in Germany: Social origins and ethnic inequality. Ethnicities 7: 343-66. [CrossRef]

Lamont, Michèle, and Virág Molnár. 2002. The Study of Boundaries in the Social Sciences. Annual Review of Sociology 28: 167-95. [CrossRef]

Michalowski, Ines, and Rickey van Oers. 2012. How Can We Categorise and Interpret Civic Integration Policies? Journal of Ethnic \& Migration Studies 38: 163-71. 
Miller-Idriss, Cythnia. 2006. Everyday Understandings of Citizenship in Germany. Citizenship Studies 10: 541-70. [CrossRef]

Onasch, Elizabeth. 2017. Lessons on the Boundaries of Belonging: Racialization and Symbolic Boundary Drawing in the French Civic Integration Program. Social Problems 64: 577-93. [CrossRef]

Schiffauer, Werner. 2006. Enemies within the Gates: The Debate about the citizenship of Muslims in Germany. In Muslims, Multiculturalism, and Citizenship. Edited by Tariq Modood. London: Routledge, pp. 94-116.

Schotte, Joachim. 2011. Orientierungskurs: Grundwissen Politik, Geschichte, und Gesellschaft in Deutschland [Orientation Course: Basic Knowledge of Politics, History, and Society]. Berlin: Cornelsen.

Simonsen, Kristina. 2016. How the host nation's boundary drawing affects immigrants' belonging. Journal of Ethnic and Migration Studies 42: 1153-76. [CrossRef]

Soysal, Yasemin N., and Hanna Schissler. 2005. The Nation, Europe, and the World. Textbooks and Curricula in Transition. New York: Berghahn.

The New York Times. 2016. Reports of Attacks on Women in Germany Heighten Tension over Migrants. The New York Times, January 5. Available online: https:/ / www.nytimes.com/2016/01/06/world/europe/ coordinated-attacks-on-women-in-cologne-were-unprecedented-germany-says.html?_r=0 (accessed on 4 April 2018).

Tonkiss, Fran. 2012. Discourse Analysis. In Researching Society and Culture. Edited by Clive Seale. Thousand Oaks: Sage, pp. 405-23.

Triandafyllidou, Anna. 1998. National identity and the 'other'. Ethnic and Racial Studies 21: 593-612. [CrossRef]

Williams, Daniel. 2013. Germanness or Rights? Second Generation Young Adults and Citizenship in Contemporary Germany. German Politics and Society 31: 30-48. [CrossRef]

Wimmer, Andreas. 2008. The Making and Unmaking of Ethnic Boundaries: A Multilevel Process Theory. American Journal of Sociology 113: 970-1022. [CrossRef]

Yuval-Davis, Nira, Kalpana Kannabrian, and Ulrike Vieten. 2006. The Situated Politics of Belonging. London and Thousand Oaks: Sage.

Zolberg, Aristine, and Litt Long Woon. 1999. Why Islam Is Like Spanish: Cultural Incorporation in Europe and the United States. Politics and Society 27: 5-38. [CrossRef]

(C) 2018 by the author. Licensee MDPI, Basel, Switzerland. This article is an open access article distributed under the terms and conditions of the Creative Commons Attribution (CC BY) license (http:/ / creativecommons.org/licenses/by/4.0/). 